\title{
Bajzát Tünde
}

\author{
Miskolci Egyetem \\ Idegennyelvi Oktatási Központ
}

\section{Szaknyelvoktatók képzettsége, oktatásmódszertana és véleménye a szaknyelvoktatásról nemzetközi kontextusban}

\author{
https://doi.org/10.48040/PL.2020.17
}

\begin{abstract}
A szaknyelvoktató feladata, hogy a hallgatók idegen nyelvi kompetenciáit szakterületüknek megfelelöen fejlessze, szakmai szókinccsel bövitse. A tanulmány célja az, hogy bemutassa egy külföldi szaknyelvoktatók körében végzett vizsgálat eredményeit. Az empirikus kutatásból megtudathatjuk a szaknyelvet oktatók képzettségét, az oktatott idegen nyelveket és szakterületeket, az oktatás során használt módszereket, a használt tananyagokat, az oktatási formákat, és az oktatók véleményét a szaknyelvoktatás- és kutatás fontosságáról a felsőoktatásban.
\end{abstract}

Kulcsszavak: felsőoktatás, szaknyelvoktatók képzettsége, oktatásmódszertan, oktatói vélemények, nemzetközi kontextus

\section{Bevezetés}

Globalizálódó világunkban az idegennyelv-tudás és a szaknyelvtudás egyre inkább felértékelődik, ezért a szaknyelvoktatás is egyre fontosabb szerepet tölt be a felsőoktatásban Magyarországon és külföldön egyaránt. Ebböl következően kutatásom célja az volt, hogy megvizsgáljam a nemzetközi kontextusban dolgozó szaknyelvoktatók munkáját és véleményét. A tanulmány a külföldi felsőoktatási intézményekben szaknyelvoktatók körében végzett empirikus kutatás eredményeit mutatja be. A kapott eredmények alapján javaslatot tehetünk arra, hogyan fejleszthető a szaknyelvoktatás a magyar felsőoktatásban azért, hogy a hallgatók jobban megfeleljenek a munkahelyi elvárásoknak itthon és nemzetközi környezetben egyaránt. A tanulmány a következőkben bemutatja a kutatás célját, módszerét, a kutatási mintát és a kutatás eredményeit.

\section{A kutatás, illetve a felmérés célja}

A felmérő kutatás célja az volt, hogy megismerjük a nemzetközi kontextusban dolgozó szaknyelvoktatók képzettségét, a szaknyelvoktatás során használt módszereket és tananyagokat, az oktatási formákat és az oktatók véleményét a szaknyelvoktatás- és kutatás fontosságáról a 
felsőoktatásban. A jelen kutatás célját tekintve alkalmazott kutatás, továbbá felhasználom a korábbi kutatások eredményeit, eszközeit, módszereit, de ugyanakkor az új kutatási felmérés révén új ismeretekkel is bővítem a témát (Fóris, 2008).

\section{A kutatás módszere}

A tanulmány következtetései egy empirikus felmérés eredményei alapján fogalmazhatók meg, ehhez az adatgyüjtés módszerei közül a kérdőíves adatfelvételt választottam. A kérdőíves adatfelvételt az egységesség, a könnyebb feldolgozhatóság indokolta. A választás másik oka az, hogy a jelen kutatás „felderítő kutatás” és a kérdőíves adatfelvétel alkalmas leginkább ilyen célra. Föként olyan kutatásokban használják, amelyekben az elemzési egység az egyes ember, illetve az adatközlők az egyes emberek. A standardizált kérdöívek továbbá minden válaszadóról ugyanolyan formában nyújtanak adatokat (Babbie, 2001).

Az angol nyelvü kérdőív zárt és nyitott kérdéseket, valamint Likertskálákat tartalmazott. A zárt kérdések esetén a lehetséges válaszokat a kutató határozza meg. A zárt kérdések egységesebb mérést követelnek meg, ezért megbízhatóságuk is nagyobb és a válaszok is könnyen összegezhetők és elemezhetők. Ezzel szemben a nyitott kérdésekre a válaszadók tetszés szerint válaszolhatnak, leírhatják gondolataikat és véleményüket, ezért a kapott adatok nem kiszámíthatók, ugyanakkor mélyrehatók (Mackey - Gass, 2005).

Az angol nyelvü kérdőív a következő témakörökre kérdezett rá:

a) a szaknyelvoktatók képzettségére és oktatási tapasztalataira;

b) az oktatott szaknyelvekre és szakterületekre;

c) az oktatás során használt módszerekre, tananyagokra és oktatási formákra;

d) az oktatók véleményére a szaknyelvoktatás- és kutatás fontosságáról a felsőoktatásban.

A kérdőíves adatgyüjtés során az önkitöltős módszert alkalmaztam, a kérdőíveket a válaszadók online töltötték ki, Google Docs formátumban. A kérdőív kitöltése önkéntes volt, a megkérdezettek megörizték anonimitásukat.

\section{A kutatási minta}

A 2019 őszén elvégzett vizsgálatban 12 külföldi felsőoktatási intézményben dolgozó szaknyelvoktató vett részt és töltötte ki a kérdőívet. A vizsgálatban résztvevők általános adatait az 1. táblázat tartalmazza. Megfigyelhetjük, hogy a megkérdezettek nagy része (11 fö, 92\%) nö, és csak 1 férfi (8\%) válaszolt a 
kérdésekre. A kutatásban résztvevők átlagéletkora 44,42 év, a válaszadók 37 és 56 éves kor közöttiek. A vizsgálatban résztvevők 17 százaléka (2 fö) 3740 éves korú. A 41-45 év közöttiek vettek részt legnagyobb számban ( 7 fö, $59 \%$ ) a kutatásban. Az életkor emelkedésével csökken a megkérdezett oktatók száma, mert 46-50 éves kor között 1 fö (8\%), 51 és 55 éves kor között 1 fö (8\%), és 55 év felett is 1 fö (8\%) van. A táblázatban látható az is, hogy a megkérdezettek négy különböző anyanyelvi csoportot képviselnek, legtöbben román anyanyelvüek ( 9 fó, $76 \%$ ), és 1-1 fó angol, német és mandarin anyanyelvü. Megfigyelhető az is, hogy a résztvevők négy különböző ország felsőoktatási intézményében oktatnak, közülük a legtöbben Romániában ( 9 fö, 76\%), 1-1 fö pedig Hollandiában, Japánban és Németországban.

1. táblázat. A vizsgálatban résztvevők általános adatai $(\mathrm{n}=12)$

\begin{tabular}{|c|c|c|}
\hline & résztvevők száma & $\begin{array}{c}\text { százalékos érték } \\
(\%)\end{array}$ \\
\hline \multirow[t]{2}{*}{ NEM } & nö: 11 & $92 \%$ \\
\hline & férfi: 1 & $8 \%$ \\
\hline \multirow[t]{6}{*}{ ÉLETKOR } & átlagéletkor: 44,42 év & --- \\
\hline & $37-40$ év között: 2 fö & $17 \%$ \\
\hline & $41-45$ év között: 7 fö & $59 \%$ \\
\hline & 46 - 50 év között: 1 fö & $8 \%$ \\
\hline & $51-55$ év között: 1 fö & $8 \%$ \\
\hline & 55 év felett: 1 fö & $8 \%$ \\
\hline \multirow[t]{4}{*}{ ANYANYELV } & angol: 1 fö & $8 \%$ \\
\hline & német: 1 fö & $8 \%$ \\
\hline & mandarin: 1 fö & $8 \%$ \\
\hline & román: 9 fö & $76 \%$ \\
\hline \multirow[t]{4}{*}{ MUNKAVÉGZÉS HELYE } & Hollandia: 1 fö & $8 \%$ \\
\hline & Japán: 1 fö & $8 \%$ \\
\hline & Németország: 1 fö & $8 \%$ \\
\hline & Románia: 9 fó & $76 \%$ \\
\hline
\end{tabular}

\section{A kutatás eredményei}

A következőkben a vizsgálat eredményeit ismertetem. Elsőként a szaknyelvoktatók képzettségét és oktatási tapasztalatait mutatom be. Ezt követően megismerhetjük a megkérdezettek által oktatott szaknyelveket és az oktatott szakterületeket. Majd az oktatás során használt tananyagok, módszerek és oktatási formák ismertetése következik. Végezetül megtudhatjuk, hogy mi a véleménye a felmérő kutatásban részt vett külföldi oktatóknak a szaknyelvoktatás- és kutatás fontosságáról a felsőoktatásban. 


\section{A szaknyelvoktatók képzettsége és oktatási tapasztalata}

A kutatásban rész vett 12 külföldi szaknyelvoktató nagy része (10 fö, 84\%) rendelkezik tudományos $(\mathrm{PhD})$ fokozattal, és a résztvevők közül csupán 2 fő $(16 \%)$ nem szerzett $P h D$ végzettséget, ők egyetemi diplomával rendelkeznek. A PhD fokozattal rendelkező válaszadók többsége ( 8 fö, $80 \%$ ) nyelvészeti területen szerezte tudományos végzettségét és kisebbik részük (2 fö, 20\%) pedig valamilyen szakmai területen.

A megkérdezettek képzettségéről az is elmondható, hogy mindannyian (12 fö, 100\%) rendelkeznek nyelvtanári végzettséggel. Azonban a külföldi szaknyelvoktatók közül csupán 2 fö (16\%) rendelkezik olyan szakterületi végzettséggel, amelynek a szaknyelvét oktatja, a többség (10 fö, 84\%) azonban nem.

A 2. táblázat a válaszadók szaknyelvoktatási tapasztalatát tartalmazza. A táblázatban látható, hogy a vizsgálatban résztvevők átlagban 14,92 év oktatási tapasztalattal rendelkeznek. Az oktatók közel fele (5 fö, 42\%) 4-10 év közötti időtartamban tanít szaknyelvet, 1 fö (8\%) 11-15 éve, az oktatók negyede (3 fö, 25\%) 16-20 év közötti tapasztalattal rendelkezik, 2 fö (17\%) 21-25 év közötti időtartamban dolgozik szaknyelvoktatóként és 1 fö (8\%) már több mint 25 éve tanít szaknyelvet.

2. táblázat. „Hány éve tanít szaknyelvet?” $(\mathrm{n}=12)$

\begin{tabular}{|l|c|}
\hline \multicolumn{2}{|c|}{$\begin{array}{c}\text { SZAKNYELVOKTATÁSI } \\
\text { TAPASZTALAT }\end{array}$} \\
\hline Korcsoport & $\begin{array}{c}\text { százalékos } \\
\text { érték (\%) }\end{array}$ \\
\hline átlag: 14,92 év & --- \\
\hline $4-10$ év között: 5 fö & $42 \%$ \\
\hline $11-15$ év között: 1 fö & $8 \%$ \\
\hline $16-20$ év között: 3 fö & $25 \%$ \\
\hline 21 - 25 év között: 2 fö & $17 \%$ \\
\hline 25 év felett: 1 fö & $8 \%$ \\
\hline
\end{tabular}

A válaszadók több mint fele (7 fö, 58\%) részesült szaknyelvoktatói képzésben korábban, de a megkérdezettek közel fele (5 fö, $42 \%$ ) nem vett részt ilyen képzésben. A külföldi szaknyelvoktatók többsége rendszeresen gyarapítja tudását konferenciákon és tréningeken. A megkérdezettek közül 1 fö ( $8 \%$ ) évente többször, negyedük (3 fö, 25\%) gyakran, harmaduk néha (4 fö, 33,5\%) másik harmaduk (4 fö, 33,5\%) ritkán vesz részt szaknyelvoktatással kapcsolatos konferencián. Tréningen ritkábban vesznek részt az oktatók: 1 fö (8\%) évente többször, harmaduk néha (4 fö, 34\%), a válaszadók fele (6 fö, 50\%) ritkán, 1 fö $(8 \%)$ pedig soha. 


\section{Az oktatott szaknyelvek és az oktatott szakterületek}

A kutatás résztvevői mindannyian (12 fö, 100\%) oktatnak angol szaknyelvet, ezen kívül 2-2 fö német, illetve román szaknyelvet is, 1-1 fö pedig francia és olasz szaknyelvet is, tehát a megkérdezettek fele (6 fö, 50\%) két különbözö idegen nyelven is tanít szaknyelvet. A megkérdezettek 13 különbözö szakterületen oktatják a szaknyelveket, melyek közül a legjelentősebb az egészségügyi (5 fö), a gazdasági (3 fö), a jogi (3 fö), a bölcsészettudományi (2 fö) és a gépészmérnöki (2 fö) szaknyelv oktatása. Azonban 1-1 fö oktató az alkalmazott fizika, anyagmérnök, építészet, földtudomány, informatika, matematika, vegyészmérnök és villamosmérnök szakterületen tanuló hallgatóknak is tart szaknyelvi órákat. A külföldi szaknyelvoktatók fele (6 fö, $50 \%$ ) heti 2 órában, egy negyedük ( 3 fö, $25 \%$ ) heti 4 órában, másik negyedük (3 fó, 25\%) csupán heti 1 órában oktat szaknyelvet.

\section{Az oktatás során használt tananyagok, módszerek és oktatási formák}

A szaknyelvi órákon a megkérdezett oktatók változatos tananyagokat használnak, a leggyakrabban használt oktatási anyagok a mások által írt kurzuskönyvek (11 fö), a saját szerzőségü kurzuskönyvek (8 fö), online videók ( 8 fö), és a Power Point-os diák (8 fö). A válaszadók gyakran használnak online cikkeket (6 fö), újság vagy magazin cikkeket (5 fö), mások által írt egyetemi jegyzeteket (4 fö) és saját szerzőségü egyetemi jegyzeteket ( 3 fö). A ritkábban használt tananyagok közé a tudományos cikkek (2 fö), az online blogok (2 fö), az online óratervek és feladataik (1 fö), a saját készítésü feladatlapok ( 1 fö) és a szakkönyvek ( 1 fö) tartoznak.

A szaknyelvi órákon használt tananyagok változatosságához hasonlóan a kutatásban résztvevők változatos módszereket alkalmaznak óráikon, melyek közül a leggyakoribbak a megbeszélés (11 fö), a szerepjáték (11 fö), az esettanulmány (10 fö) és a szeminárium (10 fö). A gyakran alkalmazott módszerek közé sorolható a projektmunka (9fö), a csoportmunka ( 8 fö) és az elöadás (6 fö). Azonban a szaknyelvi óra tematikájához kapcsolódó szakember meghívása és előadás tartása a ritkán használt módszerek közé tartozik, csupán 2 fö említette ezt meg.

Az előzőekhez hasonlóan, az oktatás során használt oktatási formák is változatos képet mutatnak. A kutatásban résztvevők leggyakrabban (11 fó) nagy csoportban (15-30 hallgató), szemináriumon (8 fó) és előadáson (7 fó) oktatnak. Kevesebben (4 fö) tanítanak kis csoportban (5-10 hallgató), 2 szaknyelvoktató folytat mentorálást és online oktatást és 1-1 fó végez távoktatást, virtuális oktatást, illetve tanít Skype-on keresztül. 


\section{Az oktatók véleménye a szaknyelvoktatás és -kutatás fontosságáról a felsőoktatásban}

Ahogyan azt a korábbiakban láthattuk, a megkérdezett szaknyelvoktatók többsége rendszeresen vesz részt szaknyelvoktatással kapcsolatos tréningen, és a válaszadók több mint fele ( 7 fö, 58\%) tartja ezt nagyon fontosnak. Az oktatók negyede ( 3 fö, 25\%) fontosnak és kis részük ( 2 fö, 17\%) közepesen fontosnak gondolja a tréningeken való részvételt.

Az előzőekben láthattuk, hogy a megkérdezett szaknyelvoktatók közül csupán 2 fö (16\%) rendelkezik olyan szakterületi végzettséggel, amelynek a szaknyelvét oktatja, és a válaszadók nagy része (10 fö, 84\%) nem is tartja ezt fontosnak. Véleményüket néhányan azzal indokolták, hogy idegen nyelvet és nem szakmát tanítanak, ezért nincs szükségük szakirányú diplomára. Erről az egyik válaszadó így írt: „,Mert én nyelvet tanitok és nem szakmai tartalmat.” Egy másik oktató pedig így vélekedett a kérdésről: „,Nem kell szakembernek lenni ahhoz, hogy szókincset tanithassunk, csak tanárnak." $\mathrm{Az}$ egyik megkérdezett véleménye szerint egy különböző szaknyelveket oktató nyelvtanártól nem várható el, hogy minden általa oktatott szaknyelv szakmai területén diplomát szerezzen. Gondolatait így fogalmazta meg: „,Ha egy tanár például angol nyelvet tanit különbözö szakos hallgatóknak (müszaki, közgazdász stb.), akkor nem rendelkezhet minden szakterületen diplomával. "Egy másik adatközlő indoklása szerint a szaknyelvoktatók célja az idegennyelv-tudás fejlesztése. Erről így írt: „Az Idegennyelvi Központunk célja a kommunikációs készségek fejlesztése idegen nyelven, és ez minden szakterületen azonos, csak egyszerüen a különbözö szakterülethez igazítjuk a tananyagot. " Azonban a válaszadók kis része (2 fö, 16\%) úgy gondolta, hogy fontos a szakirányú diploma megszerzése. Véleményét az egyik adatközlő azzal indokolta, hogy megszerzett szakmai tudása segítségével jobban tudja a szaknyelvet is oktatni. Gondolatát így fogalmazta meg: „Ezáltal jobban megértheted azt, amit tanítani fogsz." A másik válaszadó pedig, aki úgy vélekedett, hogy szakmai diplomája birtokában tudása is naprakész, erről így írt: „Azért, hogy megismerjem a legújabb trendeket."

A PhD-fokozat, tudományos tevékenység és a szaknyelvoktatáshoz való viszony

Korábban láthattuk, hogy az adatközlők nagy része (10 fö, 84\%) rendelkezik tudományos fokozattal. Azonban csupán a megkérdezettek negyede ( 3 fö, $25 \%$ ) vélte úgy, hogy nagyon fontos a $\mathrm{PhD}$ fokozat megléte szaknyelvi munkájához, 2 fö (17\%) tartotta fontosnak, a válaszadók negyede (3 fö, 25\%) közepesen fontosnak gondolta. A kutatásban résztvevők harmada (4 fö, 33\%) 
szerint egyáltalán nem fontos a tudományos fokozat megszerzése a szaknyelvoktatói munkához.

A tudományos fokozat megszerzésénél a válaszadók fontosabbnak tartják a szaknyelvoktatás területén végzett kutatómunkát. A megkérdezettek egyharmada (4 fö, 33\%) szerint nagyon fontos, 2 fó (17\%) fontosnak, másik harmaduk (4 fö, 33\%) pedig közepesen fontosnak tartja kutatás végzését a szaknyelvoktatás területén és csupán 2 fö (17\%) gondolta úgy, hogy nem fontos. Véleményük szerint a kutatómunka hozzájárul tudásuk gyarapításához, és oktatói munkájukat is fejleszti. Erről így írt az egyik adatközlő: „Mert hasznos lehet új nézöpontok megismerése.” Egy másik oktató is megerösítette ezt a véleményt: „Mert fontos, hogy naprakész legyek." Egy harmadik válaszadó ekképpen fogalmazta meg gondolatait: „Mert igy új dolgokat ismerhetek meg." Egy negyedik résztvevő így vélekedett: „Mert segíti a tanulási és tanitási folyamatot egyaránt.” Az ellenvéleményen lévők gondolata szerint a kutatómunka nem tartozik a szaknyelvoktatók legfőbb tennivalói közé, ezt így fogalmazta meg röviden egyikőjük: „,Mert a tanitás a tanár fö feladata."

\section{A szaknyelvoktatás fontosságának tanári megitélése}

Az előzőekben tárgyalt kérdésekkel összehasonlítva elmondható, hogy a megkérdezettek a szaknyelvoktatást tartják a legfontosabbnak a felsőoktatásban. A válaszadók nagy része ( 9 fö, 75\%) nagyon fontosnak, kis részük ( 3 fö, $25 \%$ ) fontosnak tartja. A megkérdezettek véleménye szerint a szaknyelvoktatás motiválja a hallgatókat, szélesíti a látókörüket, segíti szakmai elömenetelüket. Így vélekedett egyikőjük: „, Mivel az angol nyelv az akadémiai kiadványok és konferenciák fö nyelve, így fontos, hogy a nem angol anyanyelvüek is segitséget kapjanak ebben munkájukhoz." Egy másik oktató pedig ekképpen fogalmazott: ,,Mert fontos, hogy a hallgatók idegen nyelven is tudjanak beszélni szakterületükröl és szakmájukról." Továbbá, néhány oktató szerint a hallgatók jövőbeli elhelyezkedésében és munkavégzésében is kulcsfontosságú szerepet játszik, így írt erről egyikük: „Mert a munkaeröpiacon a diplomával rendelkezők számára ez elvárás." Egy másik válaszadó pedig így fogalmazta meg gondolatait: „Mert igy a hallgatók jobban el tudják majd látni a munkájukat."

A vizsgálatban résztvevők nagy része (9 fö, 75\%) egyaránt fontosnak tartja az általános és a szaknyelvoktatást a felsőoktatásban, és kis részük (3 fö, $25 \%$ ) gondolja úgy, hogy a szaknyelvoktatás fontosabb. 


\section{Konklúzió}

A tanulmány külföldi szaknyelvoktatók körében végzett empirikus felmérő kutatás eredményeit mutatta be. A vizsgálatból megtudtuk, hogy az oktatók mindannyian nyelvtanárként diplomáztak; nagy részük szerzett tudományos fokozatot; és csak kis részük rendelkezik olyan szakterületi végzettséggel, amelynek a szaknyelvét oktatja. A kutatásban részt vett szaknyelvoktatók munkájuk során változatos tananyagokat használnak, és különböző oktatási módszereket és formákat alkalmaznak. Az eredmények arra is rávilágítottak, hogy a megkérdezettek véleménye szerint egy szaknyelvet oktató tanár esetében a $\mathrm{PhD}$ fokozat megszerzése fontosabb, mint a szakmai diploma megléte; de a szaknyelvoktatással kapcsolatosan tréningen történő részvétel a legfontosabb. A válaszokból az is kiderült, hogy a válaszadók a szaknyelvkutatást is fontosnak tartják, de a szaknyelvoktatás - motiváló hatása és munkaerőpiaci elvárása miatt - fontosabb; továbbá a felsőoktatásban az általános nyelv és szaknyelvoktatása is kulcsfontosságú.

\section{Hivatkozások}

Babbie, E. (2001): A társadalomtudományi kutatás gyakorlata. Balassi Kiadó: Budapest

Fóris, Á. (2008): Kutatásról nyelvészeknek. Bevezetés a tudományos kutatás módszertanába. Nemzeti Tankönyvkiadó: Budapest

Mackey, A. - Gass, M. S. (2005): Second Language Research: Methodology and Design. Lawrence Erlbaum Associates Publishers: London 